\title{
A IMPORTÂNCIA DA CORRETA AFERIÇÃO DOS ELEMENTOS CONSTITUTIVOS DA AÇÃO REVOCATÓRIA PẢRA OS CREDORES E PARA A MASSA FALIDA
}

\author{
Alexandre Ferreira de Assumpção Alves ${ }^{1}$ \\ Thalita Almeida Salles ${ }^{2}$
}

Resumo: O artigo trata da ação revocatória como instrumento necessário para declaração de ineficácia subjetiva de atos fraudulentos praticados em prejuízo da massa falida e credores, nos termos do artigo 130 da Lei n. 11.101/2005. O objetivo é demonstrar que as decisões de improcedência nas ações revocatórias baseiam-se nas hipóteses de imperícia do administrador judicial, na dificuldade na coleta de provas e na assimetria de informações detidas pela massa falida e pelo réu. $\mathrm{O}$ método utilizado foi o dedutivo e a pesquisa bibliográfica também se apoiou no estudo de casos julgados pelo Superior Tribunal de Justiça e Tribunais de Justiça estaduais.

Palavras-chave: Falência; Massa Falida; Ineficácia Subjetiva; Ação Revocatória; Artigo 130 da Lei ${ }^{\circ} 11.101 / 2005$.

\section{THE IMPORTANCE OF THE CORRECT VERIFICATION OF REVOCATION SUIT CONSTITUENT ELEMENTS FOR CREDITORS AND FOR THE BANKRUPTCY ESTATE}

\begin{abstract}
This article discusses the revocation suit as a necessary instrument for stating subjective inefficacy of fraudulent acts performed to the loss of bankrupt estate and of creditors, as per article 130, Law\#11101/2005. The purpose is to demonstrate that revocation suits dismissal decisions are grounded on assumptions regarding lack of expertise by the court appointed administrator, difficulties in collecting evidence, and asymmetry of information held by the bankruptcy estate and by revocation suit defendant. Deductive method was adopted, and bibliographic research also leaned in the study of cases judged by the Higher Court of Justice and by Brazilian Courts of Justice.
\end{abstract}

Keywords: Bankruptcy; Bankruptcy Estate; Subjective Ineffectiveness; Revocation Suit; Article 130, Law\#11101/2005.

\section{INTRODUÇ̃̃o}

O presente artigo trata da ação revocatória enquanto instrumento necessário para declaração da ineficácia subjetiva de atos fraudulentos praticados em prejuízo da massa falida e dos credores, antes da decretação da falência, nos termos do artigo 130 da Lei nº 11.101/2005

\footnotetext{
${ }^{1}$ Mestre e Doutor em Direito. Professor Associado nas Faculdades de Direito da UERJ e da UFRJ. Docente permanente do PPGD da UERJ; alexandreas@ direito.uerj.br

${ }^{2}$ Advogada e Consultora nas áreas de Direito Empresarial, Contencioso Cível, e Contratos; sócia do escritório Bastos-Tigre, Coelho da Rocha. Lopes e Freitas Advogados. Atualmente cursa o mestrado na linha de pesquisa Empresa e Atividades Econômicas no PPGD da UERJ; thalita.almeida@bastostigre.adv.br
} 
(LRF). A relevância do tema se sustenta na utilidade de conhecer e manejar a ação revocatória que busca restituir à massa falida os bens transferidos ou cedidos a qualquer título a terceiros de forma fraudulenta. Essa importância é reforçada pela verificação do elevado número de pedidos de recuperação judicial distribuídos nos últimos anos ${ }^{3}$, evidenciando a necessidade do estudo da revocatória como medida de restituição de ativos à massa, na hipótese de restar malsucedida a recuperação judicial.

A proposta central do artigo é investigar algumas das causas de improcedência de ações revocatórias, considerando as dificuldades inerentes a esse procedimento ordinário, que demanda produção de provas de conluio e efetivo dano à massa. Para esse exame foi adotado o método dedutivo, a partir de pesquisas bibliográfica e documental, bem como da análise de precedentes coletados dos Tribunais de Justiça dos Estados de Santa Catarina, Rio Grande do Sul, Rio de Janeiro e Minas Gerais, e, ainda, do Superior Tribunal de Justiça.

No primeiro capítulo discorre-se sobre a finalidade da ação revocatória, com a apresentação de breve distinção entre as hipóteses de declaração de ineficácia de atos previstas na lei falimentar brasileira. Na sequência, foram expostas a legitimidade e os efeitos da sentença que julga procedente a ação revocatória. No capítulo seguinte perscrutou-se a fraude contra credores como elemento nucelar da ação revocatória, bem como alguns dos aspectos comparativos entre a revocatória falimentar e a ação pauliana, prevista no Código Civil de 2002. Na última parte foram analisadas ações revocatórias julgadas improcedentes, com objetivo de identificar os elementos contundentes na formação do convencimento do juízo, verificando as possíveis causas que conduzem à improcedência das ações revocatórias.

Por fim, em uma verificação preliminar dos precedentes coletados, foi possível observar que a improcedência de revocatórias falimentares funda-se, marcadamente, na imperícia do administrador judicial, dificuldade na coleta de provas e na assimetria de informações detidas pela massa falida e pelo réu da ação revocatória.

\section{FINALIDADE DA AÇÃO REVOCATÓRIA}

O vocábulo revocatória tem origem no verbo latino revocar, que significa fazer voltar,

\footnotetext{
${ }^{3}$ Segundo a Revista Valor Econômico, somente no ano de 2016, foram registrados 1.863 pedidos de recuperação judicial no país. Disponível em <https://www.valor.com.br/brasil/4824392/pedidos-de-recuperacao-judicialbatem-recorde-em-2016-nota-serasa >. Acesso em 28/08/2018.
}

Revista Brasileira de Direito Empresarial | e-ISSN: 2526-0235| Porto Alegre | v. 4 | n. 2 |

p. $79-101$ | Jul/Dez. 2018 


\section{A IMPORTÂNCIA DA CORRETA AFERIÇÃO DOS ELEMENTOS CONSTITUTIVOS DA AÇÃO REVOCATÓRIA PARA OS CREDORES E PARA A MASSA FALIDA}

restituir a, chamar de volta. (Requião, 1998, p. 224). Para Carlos Roberto Claro (2015, p. 83), a compreensão da etimologia da palavra é relevante para a correta interpretação sistemática desse instrumento do procedimento falimentar. Em sentido material, a finalidade da ação revocatória é revogar negócios jurídicos praticados no período que precede a falência, com objetivo de restituir à massa falida os bens que foram extraídos do seu ativo em conluio fraudulento com consequente prejuízo dela e dos credores do falido.

Em termos processuais, a revocatória prevista no art. 130 da LRF pode ser descrita como procedimento ordinário ("comum" na terminologia do atual CPC), de natureza constitutiva negativa, eficácia relativa e que se materializa como medida de proteção coletiva, cujo exercício só tem lugar depois da decretação da falência da devedora.

Yussef Said Cahali indica a origem da revocatória falencial nos estatutos comerciais das comunas italianas, elucidando interessante questão sobre a evolução da medida: “[...] igualmente na legislação italiana, o Código Comercial francês de 1808 [sic] adotou uma solução radical: equiparando o falido ao interdito, inquinava de nulidade abosluta atos por ele praticados desde a data da cessação de pagamentos[...].” (2013, p. 517). [grifo nosso]

O raciocínio supra é reforçado pela literalidade dos arts. $444^{4}$ e $445^{5}$ do Code de Commerce francês, nos quais se verifica tratamento de nulidade e anulabilidade aos atos fraudulentos. A mesma lógica era acompanhada pelo Código português de 1833, em seus parágrafos. $1.136^{6}$ e $1.137^{7}$, pelo Código Comercial de 1850 , no artigo $828^{8}$, pelo Decreto n. 917 de 1890, no seu artigo 30, $b^{9}$, bem como pela Lei n. 859 de 1902, em seu artigo 36, $\mathrm{b}^{10}$.

\footnotetext{
${ }^{4}$ Art. 444. Tous actes translatifs de propriétés immobilières, faits par le failli, à titre gratuit, dans les dix jours qui précèdent l'overture de la faillite, sont nuls et sans effect relativement à la masse des créanciers; tous actes du même genre, à titre onéreux, sont susceptibles d'être annullés, sur la demande des créanciers, s'ils paraissent aux juges porter des caractères de fraude.

${ }^{5}$ Art. 445. Tous actes ou engagemens pour fait de commerce, contractés par le débiteur dans les dix jours qui précèdent l'overture de la faillite, sont présumés frauduleux, quant au failli: ils sont nuls, lorsqu'il est prouvé qu'il y a fraude de la part des autres contractans.

${ }^{6}$ Art. 1.136. Todos os atos translativos de propriedade móve1 ou de raiz, a titulo oneroso, todas as obrigações, todos os pagamentos feitos em qualquer época podem ser anulados a requerimento dos credores, provando-se fraude de qualqner das partes.

${ }^{7}$ Art. 1.137. Todos os atos ou obrigações, contraídas pelo devedor com fim comercial nos vinte dias precedentes à abertura da falência, presumem-se fraudulentos quanto ao falido; e são nulos, provando-se que houve fraude da parte dos outros contratantes.

${ }^{8}$ Art. 828 - Todos os atos do falido alienativos de bens de raiz, móveis ou semoventes, e todos os mais atos e obrigações, ainda mesmo que sejam de operações comerciais, podem ser anulados, qualquer que seja a época em que fossem contraídos, enquanto não prescreverem, provando-se que neles interveio fraude em dano de credores.

${ }^{9}$ Art. 30. São anuláveis somente em beneficio da massa: b) todos e quaisquer atos, seja qual for a época em que tenham sido feitos, sem que se possa alegar prescrição ordinária, provando-se fraude de uma e outra parte contratante.
} 
Interessante notar que o Código Comercial espanhol de 1829, parece ter inaugurado a distinção entre os atos anuláveis, previstos no art. $1.041^{11}$, e a revocação (revocar) para os atos praticados en fraude de sus acreedores (revocação), nos termos do art. $1.042^{12}$.

No Brasil, com a promulgação da Lei n. 2.024, de 1908, finalmente ocorreu a distinção dos efeitos que se pretendia emprestar aos atos que, objetivamente, não seriam oponíveis à massa falida (art. 55) ${ }^{13}$, e a revogação de atos praticados de forma fraudulenta na forma do art. $56^{14}$. A redação do dispositivo legal que previu a ação revocatória não sofreu alteração substancial no Decreto n. 5.746 , de 1929 , nos seus arts. $55^{15}$ e $56^{16}$, seguido do Decreto-lei n. 7.661, de 1945, que previu as medidas de ineficácia em seus arts. $52^{17}$ e $53^{18}$.

$\mathrm{Na}$ legislação falimentar vigente, a revocatória se acha prevista no Capítulo $\mathrm{V}$ da Lei n. 11.101/2005, que trata da ineficácia objetiva e da revogação ${ }^{19}$ de atos praticados antes da falência em seus arts. 129 e 130. No artigo 129 e seus incisos estão previstas as hipóteses de ineficácia objetiva e, no artigo 130, as de ineficácia subjetiva. É fundamental fazer a distinção entre as situações previstas nesses dois dispositivos, porque ela se reflete na correta aferição dos elementos necessários para aplicação de um ou de outro procedimento, bem como da necessidade ou dispensa de produção de determinadas provas.

\subsection{Distinção entre as hipóteses de ineficácia previstas nos artigos 129 e 130 da LRF}

\footnotetext{
${ }^{10}$ Art. 36. São anuláveis somente em beneficio da massa: b) todos e quaisquer actos, seja qual for a época em que tenham sido feitos, sem que se possa alegar prescrição, provando-se fraude de uma e outra parte contratante.

${ }^{11}$ Art. 1041. Podrán anularse á instancia de los acreedores, mediante la prueba de haberse obrado en fraude de sus derechos: [...].

${ }^{12}$ Art. 1042. Todo contrato hecho por el quebrado en los cuatro años anteriores á la quiebra , en que se pruebe cualquiera especie de suposicion ó simulacion hecha en fraude de sus acreedores, se podrá revocar á instancia de estos.

${ }^{13}$ Art. 55. Não produzirão efeito relativamente à massa, tenha ou não o contratante conhecimento do estado econômico do devedor, seja ou não intenção deste fraudar os credores: [...].

${ }^{14}$ Art. 56. Poderão ser revogados, também, relativamente à massa, todos e quaisquer atos, enquanto não prescritos, praticados pelo devedor, na intenção de prejudicar credores, provando-se fraude de ambos os contraentes.

15 Art. 55. Não produzirão efeitos relativamente à massa, tenha ou não o contratante conhecimento do estado econômico de devedor, seja ou não intenção deste fraudar os credores: [...]

${ }^{16}$ Art. 56. Poderão ser revogados, também relativamente à massa, todos o quaisquer atos, enquanto não prescritos, praticados pelo devedor, na intenção do prejudicar credores, provando-se fraude, de ambos os contraentes.

17 Art. 52. Não produzem efeitos relativamente à massa, tenha ou não o contratante conhecimento do estado econômico do devedor, seja ou não intenção deste fraudar credores: [...]

${ }^{18}$ Art. 53. São também revogáveis, relativamente à massa, os atos praticados com a intenção de prejudicar credores, provando-se a fraude do devedor e do terceiro que com ele contratar.

${ }^{19} \mathrm{O}$ termo revogação não é etimologicamente adequado para tratar da revocatória, mas foi utlizado no texto, em razão de sua propagação na doutrina e nos textos legais. No entanto, é pertinente registrar que o sentido que se deve emprestar ao termo é de revocar (chamar para trás, mandar voltar) e não de revogar (tornar sem efeito, anular, desfazer, fazer com que não mais vigore). (CLARO, 2015, p. 146)
} 
Apesar de ser comum o objetivo dos arts. 129 e 130 da LRF, isto é, declarar a ineficácia de determinado negócio jurídico em relação à massa falida, há diferenças de natureza procedimental e material que separam as duas hipóteses. Enquanto a declaração de ineficácia objetiva pode ser reconhecida e declarada de ofício pelo juiz, os efeitos pretendidos com a ineficácia subjetiva dependem do ajuizamento da ação revocatória, com a necessária demonstração do fato constitutivo do direito do autor, com a necessária observância dos requisitos da petição inicial, nos termos do art. 319 do Código de Processo Civil e da comprovação do consilium fraudis e do eventus damni.

Além disso, a declaração de ineficácia objetiva somente pode se dar nas situações previstas pelo art. 129, enquanto que a ação revocatória prevista no art. 130 tem cabimento apenas quando houver fraude no ato que se pretende revogar, sem necessidade de que o ato esteja especificamente previsto pela lei, como ocorre no primeiro caso. A esse respeito, traz-se à colação escólio de Carlos Roberto Claro (2015, p. 272): “[...] na revocatória falimentar, cabe prova robusta a respeito dos fatos; na ação declaratória de ineficácia relativa de ato, basta a subsunção do fato concreto à letra da lei (art. 129)".

Nos termos do artigo 129, os atos são tidos por objetivamente ineficazes em relação à massa, mesmo que provada a boa-fé do terceiro contratante, tendo este conhecimento ou não do estado econômico do devedor, haja ou não a intenção de fraudar credores. Assim, se o ato atacado se subsumir a uma das hipóteses do artigo 129, será desnecessária a produção da prova do consilium fraudis. Trata-se, portanto de presunção absoluta, juris et de jure. ${ }^{20}$

A simples leitura dos incisos I, II e III do artigo 129 permite concluir que o dispositivo cuida de atos praticados dentro do termo legal da falência e prevê como objetivamente ineficazes em relação à massa: (i) o pagamento de dívidas não vencidas; (ii) o pagamento de dívidas vencidas e exígiveis, por qualquer forma que não seja a prevista pelo contrato; e (iii) o favorecimento de dívida contraída em data anterior com a constituição (posterior) de direito real de garantia, incluindo a retenção. Em todos é requisito fundamental a prática do ato dentro do termo legal. Sobre esse termo, Antonio Martin esclarece:

Salienta-se na doutrina moderna a importância da fixação do termo legal de forma mais ampla. De fato, em legislações passadas, chegou-se a falar em 40 (quarenta) dias

\footnotetext{
${ }^{20}$ Análise mais completa dessa questão pode ser verificada no acórdão exarado pela Quarta Turma do STJ no Agravo Interno em Recurso Especial n. 901.010/SC, julgado em 23/08/2016, sob a relatoria do Min. Luis Felipe Salomão.
}

Revista Brasileira de Direito Empresarial | e-ISSN: 2526-0235| Porto Alegre | v. 4 | n. 2 |

p. $79-101$ | Jul/Dez. 2018 
e no Dec.-lei 7.661/1945 deixou-se esta fixação a critério do Juízo, que poderia fixálo em até 60 (sessenta) dias. Agora, na Lei 11.101/2005, o termo legal é de 90 (noventa) dias contados do pedido de falência, ou do pedido de recuperação judicial, ou do primeiro protesto por falta de pagamento, excluindo-se, para esta finalidade, os protestos que tenham sido cancelados. Como se vê do texto da Lei, a fixação do termo legal tem importância decisiva para a declaração de ineficácia dos atos nela mencionados. (2007, p. 473)

Já os incisos IV e V do mesmo artigo têm por objetivamente ineficazes em relação à massa, nos dois anos que precedem a decretação da falência, a prática de atos a título gratuito, e a renúncia à herança ou a legado. No que se refere ao inciso IV, Ricardo Tepedino comenta:

\begin{abstract}
A constituição de gratuita de usufruto, o comodato e o mútuo não feneratício são alcançados pelo espectro de ação do dispositivo. Não há aqui uma diminuição patrimonial propriamente dita, mas sim a abdicação de auferir proveito, como o aluguel ou os juros compensatórios. Em outras palavras, em havendo liberalidade (e outros exemplos podem ser imaginados: renúncia a direitos, inclusive de garantia, remissão de dívidas, prestação gratuita de serviços etc.), abre-se campo para a atuação da norma em foco. Nessas hipóteses, a ineficácia não atingirá o negócio juridico, mas sim a dispensa tácita de contraprestação por parte de seu beneficiário, que deverá ser condenado a ressarcir à massa o que ela deixou de embolsar, em montante a ser apurado em processo cognitivo. (2016, p. 493)
\end{abstract}

Com base nos precedentes judiciais a serem analisados, o inciso VI do art.129 parece ser o de interpretação mais tormentosa para os autores da ação revocatória e para os julgadores. O dispositivo trata da ineficácia do trespasse de estabelecimento, realizada sem o consentimento dos credores a esse tempo existentes. Tal misuso poderia ser evitado se o autor da ação revocatória verificasse a correta aplicação do dispositivo legal. Eventuais dúvidas sobre o conceito de estabelecimento e as condições para o consentimento prévio dos credores poderiam ser dirimidas por consulta aos arts. 1.142 e $1.145^{21}$ do Código Civil.

Do conceito da norma cível, compreende-se que é possível requerer a declaração de ineficácia objetiva em relação à massa, quando a hipótese versar sobre a alienção dos bens essenciais ao exercício da atividade da falida. Por essa razão, quando o negócio jurídico versa sobre um bem móvel ou imóvel, que não esteja relacionado ou não seja necessário ao exercício da empresa antes da falência, a aplicação do dispositivo se torna equivocada.

No que diz respeito à interpretação do inciso VII do art. 129, não há celeuma, uma vez que o texto legal determina clara e expressamente que serão objetivamente ineficazes em

\footnotetext{
${ }^{21}$ Art. 1.142. Considera-se estabelecimento todo complexo de bens organizado, para exercício da empresa, por empresário, ou por sociedade empresária.

Art. 1.145. Se ao alienante não restarem bens suficientes para solver o seu passivo, a eficácia da alienação do estabelecimento depende do pagamento de todos os credores, ou do consentimento destes, de modo expresso ou tácito, em trinta dias a partir de sua notificação.
} 


\title{
A IMPORTÂNCIA DA CORRETA AFERIÇÃO DOS ELEMENTOS CONSTITUTIVOS DA AÇÃO REVOCATÓRIA PARA OS CREDORES E PARA A MASSA FALIDA
}

relação à massa os atos pertinentes à transferência de ativos praticados após decretação da falência, à exceção daqueles que possuírem prenotação anterior.

Ao contrário, o art. 130 condiciona a decretação de ineficácia à ampla demonstração do conluio fraudulento e do dano causado à massa e aos credores. Assim, as hipóteses de negócios jurídicos que não tenham sido expressamente mencionadas no art. 129 demandam a produção de prova do consilium fraudis em ação própria ajuizada tempestivamente (art. 132).

Conforme se demonstrará por meio das decisões judiciais coligidas e analisadas, não raro a imperícia na utilização desses dispositivos legais (arts. 129 e 130) é elemento central do insucesso de medidas judiciais que buscam a declaração de ineficácia de determinado negócio jurídico em relação à massa falida. A imperícia incide na pressuposição de que determinado ato poderá ser declarado ineficaz nos termos do artigo 129, quando, na verdade, a hipótese se enquadra no artigo 130 e demanda a produção da prova de fraude e de dano concreto. Nas palavras de Trajano de Miranda Valverde (1999, p. 376):

\begin{abstract}
A ineficácia dos atos especificados no art. 52 [atual art. 129 da LRF] está para a ineficácia de que se cogita o artigo 53 [atual art. 130 da LRF], como a nulidade em relação à anulabilidade. $\mathrm{O}$ fato da falência, por si só, determina a ineficácia dos atos discriminados no art. 52. A fraude, entretanto, é necessária para conseguir-se a decretação da ineficácia dos atos a que alude o art. 53. Distribuem, por isso, os nossos escritores, os atos jurídicos que, em relação a massa falida, não produzem ou não podem produzir efeitos, em dois grupos: atos ineficazes e atos revogáveis.
\end{abstract}

Muito embora as diferenças pareçam bem delimitadas na legislação, a distinção não é de aplicação óbvia na prática. Isso se afirma especialmente nos casos em que a parte dispensa a produção da prova do consilium fraudis e do dano, assumindo tratar-se de uma das hipóteses do art. 129, quando o caso comportava clássica aplicação do art. 130, reclamando, portanto, ajuizamento da ação revocatória e produção de prova quanto ao conluio fraudulento.

Também caberá pretensão revocatória se verificada a proximidade da falência do devedor, em face do pagamento realizado em favor do ex-acionista retirante, se ao tempo do reembolso este não tiver sido substituído, com ingresso de novos recursos no capital da companhia, em quantia equivalente ao do reembolso pago. Nessa hipótese, caberá pretensão revocatória para devolução do reembolso, nos termos do $\S 8^{\circ}$ do art. 45 da Lei n. 6.404/ 76.

É pertinente distinguir os recursos cabíveis nas hipóteses de acolhimento ou rejeição dos pedidos de declaração de ineficácia e do pedido de revogação. Sendo proclamada a ineficácia objetiva incidentalmente no processo falimentar, caberá o recurso de agravo de instrumento (art. 1.015, II, do CPC). Contra a sentença de procedência ou improcedência da 
ação revocatória cabe apelação, nos termos do parágrafo único do art. 135 da LRF.

Verificadas algumas das distinções entre as situações previstas nos arts. 129 e 130 da LRF, torna-se importante analisar a legitimição para propositura da ação revocatória.

\title{
1.2 Legitimidade para a Ação Revocatória
}

Nos termos do art. 132 da LRF, a ação revocatória poderá ser proposta, alternativamente, pelo administrador judicial, por qualquer credor ou pelo Ministério Público, no prazo de 3 (três) anos da decretação da falência. Os mesmos legitimados podem reclamar a declaração da ineficácia objetiva, prevista no art. 129 e incisos da $\operatorname{LRF}^{22}$.

A LRF inovou em relação à legislação precedente ao acrescer no rol dos legitimados para propositura da ação revocatória o Ministério Público, sendo pertinente lembrar que a atuação do parquet, do administrador judicial ou do credor interessado para propositura da ação revocatória se dará sempre em favor da massa. A respeito Yussef Said Cahali pontua:

\begin{abstract}
Na realidade, há muita discussão acadêmica quanto à legitimatio ativa da ação - se o administrador judicial ou se da massa -, na medida em que não ocorre uma antinomia entre os conceitos apresentados, pois, em síntese, o administrador judicial atua em nome da massa, da qual é representante, na defesa dos interesses da coletividadede de credores, e no exercício de uma atribuição que interessa à correta prestação jurisdicional do Estado.” (2013, p. 619)
\end{abstract}

Embora o art. 132 da LRF mencione como um dos autores o "administrador judicial", é a massa falida que deve figurar no polo ativo da revocatória, sendo que aquele não se beneficia da ação, por se tratar de medida de proteção coletiva. (LEONEL, 1951, p.26).

Em relação ao polo passivo, o art. 133 da LRF prevê que podem ser demandados: (a) os que figuraram no ato ou que por efeito dele foram pagos, garantidos ou beneficiados; (b) terceiros adquirentes, se tiveram conhecimento, ao se criar o direito, da intenção do devedor de prejudicar os credores; e (c) os herdeiros ou legatários dos sujeitos referidos anteriormente.

Jayme Leonel esclarece a desnecessidade de citação do falido:

\begin{abstract}
A razão é simples. Decretada a falência, perde o falido, em consequência do princípio do desapossamento, o direito de comparecer pessoalmente em juízo, quer ativa, quer passivamente. [...] Logo, se o falido tivesse de ser citado, como réu, na revocatória, iríamos segundo arguta observação de MARCONDES FILHO, encontrar, no processo, esta situação paradoxal: - o liquidatário (hoje, o síndico), em tais processos, teria de figurar, ao mesmo tempo, como autor, impugnando o ato do falido, e, como réu, para defender a validade do mesmo. (1951, p. 29-30)
\end{abstract}

22 O parágrafo único do artigo 129 prevê que a ineficácia pode ser declarada de ofício pelo juiz, alegada
incidentalmente no curso do processo falencial ou mediante a propositura de ação própria. 


\title{
A IMPORTÂNCIA DA CORRETA AFERIÇÃO DOS ELEMENTOS CONSTITUTIVOS DA AÇÃO REVOCATÓRIA PARA OS CREDORES E PARA A MASSA FALIDA
}

Esclarecida a questão quanto à legitimidade na ação revocatória, é necessário tratar dos efeitos provocados pela sentença que julga procedente o pedido, e cuja consequência está distante da obviedade que se pode pressupor.

\subsection{Efeitos da sentença que julga procedente ou improcedente o pedido revocatório}

Nos termos do art. 135 da LRF, a procedência da ação revocatória tem como efeito imediato a determinação de retorno dos bens à massa falida em espécie, com todos os acessórios, acrescidos de perdas e danos. O dispositivo ratifica o objetivo da ação, que é de devolver à massa os bens extraídos do seu ativo de forma fraudulenta antes da falência. Assim, não importa que um credor, de qualquer classe, tenha se sub-rogado nos direitos da massa para ingressar com a ação revocatória. Com o retorno dos bens à massa, eventual pagamento estendido aos credores da falência respeitará a ordem de preferência prevista no art. 83 da LRF, não sendo determinante, para fins de recebimento, a atuação de determinado credor na revocatória, por se tratar de medida de defesa coletiva.

Cabe esclarecer que o efeito da revocatória não é anular o ato, como se jamais praticado, e sim garantir o restabelecimento do status quo ante em relação à massa e não ao falido. Portanto, a sentença de procedência da ação revocatória não opera efeitos de anulação do ato, mas de ineficácia relativa, deixando de produzir efeitos apenas em relação à massa e conservando sua validade interpartes. A respeito, Yussef Said Cahali comenta:

\begin{abstract}
A sentença que julga a ação revocatória decide quanto à eficácia do ato do falido, em relação à massa, não quanto a sua validade jurídica erga omnes, ou nulidade; o ato jurídico não é desconstituído na sua formação, nem fica insubsistente in totum, mas apenas deixa de ser oponível em relação aos créditos concursais; portanto, continua válido entre as partes, com possibilidade de oportuna pós-eficacização. (Rubens Requião, Pontes de Miranda, Jayme Leonel, Walter T. Álvares, Rubens Aguiar) [...] Efetivamente, encerrada a falência e extintas as obrigações do falido, o ato atingido pela revocatória readquire sua vigência entre aquele que veio a falir e o que com ele contratara. $(2013$, p. 602)
\end{abstract}

Outro efeito da sentença de procedência do pedido é a possibilidade de decretação mesmo se o ato estiver amparado por decisão judicial, nos termos do art. 138 da LRF. Assim, os atos praticados com base em decisão judicial poderão ter sua eficácia atingida, tornando sem efeito, em relação à massa, inclusive decisões transitadas em julgado. $\mathrm{O}$ dispositivo é alvo de críticas na doutrina, conforme sintetiza Carlos Roberto Claro (2015, p. 286):

Como visto, por força do regramento incutido no art. 138 da Lei de Regência (e art.

58 do Decreto-lei ab-rogado), casos há em que a sentença julga procedente o pedido 
formulado na demanda ajuizada pelo administrador judicial, ou terceiros legitimados pelo atual texto de lei, terá força até mesmo em relação à anterior decisão judicial, proferida em outro processo que envolva interesses jurídicos da massa falida. Evidentemente, pois, que talvez tal dispositivo legal seja uma (total) incongruência, e venha a aguilhoar o princípio da segurança jurídica, mas o legislador ordinário, mais uma vez, colocou na balança os interesses da massa falida, de um lado, e os do devedor e terceiro contratante, de outro.

Decretada a ineficácia, as partes retornarão ao estado anterior e o contratante de boa-fé terá direito à restituição dos bens ou valores entregues ao devedor. Contudo, não caberá ação revocatória na situação prevista no art. 136, § $1^{\circ}$, da LRF, hipótese de cessão de créditos securitizados em prejuízo dos titulares de valores mobiliários emitidos pelo securitizador. Verificados, sucintamente, os efeitos da revocatória falimentar, é pertinente tratar da fraude, elemento central de sustentação do pleito da ação.

\section{FRAUDE CONTRA CREDORES COMO ELEMENTO SUBJETIVO E NUCLEAR DA AÇÃO REVOCATÓRIA}

Tratar de ação revocatória pressupõe a fraude como elemento nuclear dessa ação. Nas palavras de Carlos Roberto Gonçalves (2007, p. 410):

Fraude contra credores é, portanto, todo ato suscetível de diminuir ou onerar seu patrimônio, reduzindo ou eliminando a garantia que este representa para pagamento de suas dívidas, praticado por devedor insolvente, ou por ele reduzido à insolvência. [grifo do autor]

A fraude contra credores é constituída por dois elementos essenciais, o primeiro, de caráter objetivo, eventus damni, constatado pela expressiva redução da capacidade de o devedor saldar suas dívidas e o segundo, de caráter subjetivo, consilium fraudis, que se materializa quando o devedor e o terceiro que com ele contrata, mesmo cientes do prejuízo causado aos credores, praticam determinado ato. (GONÇALVES, 2007, p. 411)

Na clássica doutrina de Jayme Leonel (1951, p. 86), o autor desconstroi a ideia (equivocada) de que o conluio fraudulento deve ser comprovado com a demonstração da intenção do devedor e do terceiro, que com ele contratou, de prejudicar credores:

[...] consilium fraudis, que não é propriamente a intenção de prejudicar. Consiste a fraude do devedor na consciência de que o ato, que vai executar, pode prejudicar, ou prejudicará, certamente, os seus credores; e a fraude do terceiro, na sua participação no ato com a conciência do dano que será causado aos credores do fraudator.

Destarte, a presunção de má-fé do adquirente pode ser concluída quando estiverem 
para ele (adquirente) ampla e facilmente acessíveis informações públicas que noticiam o estado de dificuldade financeira enfrentada pelo devedor, pois a boa-fé que se espera na prática de negócios jurídicos é de caráter objetivo e demanda a coleta de informações (e até de certidões) que atestem a idoneidade da operação e demonstrem a adoção de cuidados mínimos no momento de contratar. Sobre o tema, Carlos Roberto Gonçalves sumariza:

$\mathrm{O}$ art. 159 do Código Civil presume a má-fé do adquirente "quando a insolvência (do alienante) for notória, ou houver motivo para ser reconhecida do outro contratante". A notoriedade da insolvência pode se revelar por diversos atos, como, por exemplo, pela existência de títulos de crédito protestados, de protestos judiciais contra alienação de bens e de várias execuções ou demandas de grande porte movidas contra o devedor. (2007, p. 411)

A tormentosa produção da prova do consilium fraudis foi tratada em decisão proferida pela Quarta Turma do STJ, no Agravo Interno do Recurso Especial n. 1.294.462/GO, julgado em 19/10/2017, seguindo voto-vista do Ministro Luis Felipe Salomão. Por meio da referida decisão, fica demonstrado que a intenção de causar dano ao credor não é indispensável na configuração da fraude, bastante que o ato seja capaz de levar o devedor à insolvência e que o terceiro adquirente tenha conhecimento desse estado:

\section{AGRAVO INTERNO NO RECURSO ESPECIAL. [...]}

1. A ocorrência de fraude contra credores demanda a anterioridade do crédito, a comprovação de prejuízo ao credor (eventus damni), que o ato jurídico praticado tenha levado o devedor à insolvência e o conhecimento, pelo terceiro adquirente, do estado de insolvência do devedor (scientia fraudis). [...] [grifo nosso]

O precedente acima colacionado consolida posicionamento da doutrina e da majoritária jurisprudência que entende comprovado o consilium fraudis quando se consegue demonstrar a scientia fraudis, isto é, que o terceiro adquirente tinha conhecimento do estado de insolvência do devedor com quem contratou. De outro modo, exigir a comprovação da intenção de fraudar credores ou de conluio, seria exigir do autor da ação a produção da conhecida prova diabólica, ou impossível de ser produzida.

A perfeita compreensão dos elementos que constituem a fraude é fundamental quando se trata da ação revocatória, bem como da ação pauliana prevista nos arts. 158 e 159 do Código Civil. A demonstração da fraude é requisito nuclear para o credor interessado propor a revocatória prevista na lei falimentar, bem como na ação pauliana do Código Civil. Embora estejam previstas em diferentes legislações, a ação revocatória e a ação pauliana têm similaridade instrínseca, que é a necessidade de comprovação do conluio fraudulento. 


\subsection{Aspectos Comparativos das Ações Revocatória e Pauliana: similaridades e diferenças}

A ação pauliana tem origem no direito romano e é assim denominada como referência ao pretor Paulo. A medida foi criada para coibir a prática de atos fraudulentos por parte do devedor (CAHALI, 2013, p. 83). A ação revocatória, objeto de análise desse trabalho, possui muitas similaridades com a ação pauliana. Segundo Jayme Leonel "Muitos autores chegam a afirmar que elas são absolutamente idênticas” (1951, p. 83). Não é possível afirmar, contudo, que a ação revocatória e a ação pauliana sejam idênticas, porque existem diferenças substanciais entre elas. A primeira diferença pode ser apontada quanto ao momento de ajuizamento das ações. Na ação pauliana, basta que o crédito preexista ao ato que pretende anular para intentar sua propositura. Já na ação revocatória falencial, a decretação da falência do devedor é pressuposto de cabimento da medida.

Se na ação pauliana o devedor deve integrar o polo passivo em litisconsórcio com o terceiro adquirente de má-fé, nos termos do art. 161 do Código Civil, a ação revocatória não comporta esta hipótese, uma vez que a massa falida é autora. Tal providência se justifica porque a massa falida se aproveita da revogação do ato jurídico cuja ineficácia se pretende decretar, pois os bens serão a ela restituídos com a procedência do pedido e não aos credores.

Não obstante as distinções quanto ao procedimento, tanto a ação revocatória como a ação paulina têm como finalidade a devolução dos bens necessários para cumprimento das obrigações do falido perante seus credores. Sobre o tema, cite-se escólio do Recurso Especial n. 1.180.714/RJ, julgado em 05/04/2011, de relatoria do Ministro Luis Felipe Salomão:

[...] A primeira (revocatória) visa ao reconhecimento de ineficácia de determinado negócio jurídico tido como suspeito, e a segunda (pauliana) à invalidação de ato praticado em fraude a credores, servindo ambos os instrumentos como espécies de interditos restitutórios, no desiderato de devolver à massa, falida ou insolvente, os bens necessários ao adimplemento dos credores, agora em igualdade de condições (arts. 129 e 130 da Lei n. 11.101/05 e art. 165 do Código Civil de 2002). [...]

Para procedencia da ação revocatória e da ação pauliana são meios de prova admissíveis no procedimento comum os indícios da prática de fraude. José Xavier Carvalho de Mendonça (1964, p. 567-8) cita como exemplos que levam à presunção de fraude:

a) a clandestinidade do ato; $b$ ) a continuação de bens alienados na posse do devedor, quando, segundo a natureza do ato, deviam passar para o terceiro; $c$ ) a falta de causa do ato ou do contrato; $d$ ) o parentesco ou afinidade entre o devedor e o terceiro; $e$ ) o preço vil; $f$ ) a proximidade da falência; $g$ ) a alienção de todos os bens; $h$ ) a multiplicidade de atos para encobrir a verdade; multiplicatione instrumentorum augetur fraudis et similations proesumptio; i) a compra de bens por quem não está na 
livre administração de seus bens e viva de simples mensalidade.

A referida doutrina é corroborada pela decisão de procedência da ação revocatória da Segunda Câmara de Direito Público do Tribunal de Justiça de Santa Catarina, no Recurso de Apelação n. 20120861326, julgado em 22/07/2013, sob a relatoria do Desembargador Cid Goulart, verificando-se a presença de alguns dos elementos acima indicados:

APELAÇÃO CÍVEL E REEXAME NECESSÁRIO - AÇÃO REVOCATÓRIA ARREMATAÇÃO JUDICIAL DE BENS QUE INTEGRAVAM O PATRIMÔNIO DA MASSA FALIDA, ANTERIORMENTE À DECRETAÇÃO DA QUEBRA, POR EMPRESA CONSTITUIIDA, VIA OFFSHORE COMPANY SITUADA NO URUGUAI, VINCULADA AOS SÓCIOS DAQUELA - CONSILIUM FRAUDIS EVIDENCIADO, COM FLAGRANTE PREJUÍZO AOS CREDORES - SENTENÇA DE PROCEDÊNCIA MANTIDA [...]. "São revogáveis os atos praticados com a intenção de prejudicar credores, provando-se o conluio fraudulento entre o devedor e o terceiro que com ele contratar e o efetivo prejuízo sofrido pela massa falida", "ainda que praticado com base em decisão judicial" (artigos 130 e 138 da Lei n. 11.101/2005). "[...] é irrelevante a época em que foi praticado, próxima ou distante da decretação da falência" [...]. [grifos nossos]

O precedente trazido à colação revela exemplo comum da prática de atos_fraudulentos, realizados em prejuízo dos direitos dos credores e da massa falida.

\section{A IMPORTÂNCIA DA CORRETA AFERIÇÃO DOS ELEMENTOS DA AÇÃO REVOCATÓRIA PARA OS CREDORES E MASSA FALIDA: análise jurisprudencial}

É momento de investigar o problema aqui debatido - a correta aferição dos elementos constitutivos da ação revocatória - com objetivo de identificar as causas centrais de sua improcedência. Os seis precedentes coligidos e analisados revelam certa recorrência na inadequada instrução do pedido, bem como imperícia na utilização do dispositivo destinado à ação revocatória, conforme se constata adiante.

Caso 1: a decisão da Quarta Turma do STJ no Recurso Especial n. 1.197.723/SP, julgado em 19/10/2010, sob a relatoria do Min. João Otávio de Noronha, demonstra que não houve atenção por parte da massa falida autora à crucial diferença entre alienação de estabelecimento e dos bens a ela pertencentes:

AÇÃO REVOCATÓRIA. FALÊNCIA. ILEGITIMIDADE PASSIVA DO FALIDO. VENDA DE IMÓVEL ANTES DA DECRETAÇÃO DA QUEBRA, DENTRO DO TERMO LEGAL. FRAUDE NÃO DEMONSTRADA. EFICÁCIA DO NEGÓCIO JURÍDICO. ARTS. 52 E 53 DA ANTIGA LEI DE FALÊNCIAS. [...] 2. Com a decretação da quebra, há a perda da legitimação ativa e passiva do falido para atuar na ação revocatória falimentar, como consequência lógica da impossibilidade de dispor de seus bens e de administrá-los, na medida em que os interesses patrimoniais passam a ser geridos e representados pelo síndico da massa falida. 3. A ineficácia da venda de imóvel pela empresa antes da decretação da sua falência, dentro do

Revista Brasileira de Direito Empresarial | e-ISSN: 2526-0235| Porto Alegre | v. 4 | n. 2 |

p. $79-101$ | Jul/Dez. 2018 
período suspeito, depende da prova concreta da fraude, consoante orientação firmada no STJ. [...]. Ação revocatória improcedente. [grifos nossos]

A massa falida, representada por seu síndico dativo, ingressou com ação revocatória com fulcro no artigo 52, VIII, do Decreto-lei n.7.661/45 (correspondente ao art. 129, VI, da LRF), objetivando ver declarada a ineficácia da venda do imóvel integrante do estabelecimento, alienado dentro do termo legal. Tratava-se de terreno vazio, posteriormente fracionado em duas partes e alienado a terceiros, que também se tornaram réus na ação.

Apesar de se ter reconhecido na fundamentação do pedido que a alienção se deu dentro do termo legal, os terceiros adquirentes sustentaram, no mérito, ofensa ao artigo 53 do Decreto-lei n. 7.661/45 (correspondente ao art. 130 da LRF), alegando necessária comprovação do consilium fraudis. O pedido foi julgado procedente em $1^{\mathrm{a}} \mathrm{e} 2^{\mathrm{a}}$ instâncias, tendo se verificado que a alienação ocorreu dentro do termo legal, motivo pelo qual o ato foi considerado objetivamente ineficaz em relação à massa.

A improcedência do pedido de ineficácia somente foi reconhecida quando o recurso foi apreciado pela Quarta Turma do STJ, sob o argumento de que o imóvel objeto da ação revocatória não integrava o estabelecimento da falida e, assim, não constituía parte necessária à realização do objeto da sociedade. Segundo entendimento dos julgadores, essa era a razão para que o artigo 52, VIII, previsse a ineficácia do negócio, ao menos em relação à massa falida. Nesse caso, a Turma entendeu que o bem alienado era um lote vazio, situado em local diferente daquele onde funcionava o restaurante (empresa da devedora). Ademais, não havia nos autos qualquer prova demonstrando a direta conexão do referido lote às atividades da sociedade; tampouco foram produzidas as provas necessárias à desconstituição do ato.

No caso apresentado, ficou patente que a imperícia na utilização dos dispositivos legais da falência foi decisiva para a improcedência final do pedido. Isso porque, a autora deveria, desde a distribuição da ação, ter identificado o dispositivo legal aplicável, pois se trata de ineficácia subjetiva (e não objetiva), e, consequentemente, ter dedicado atenção à coleta das provas necessárias (demonstração do consilium fraudis e eventus damni) à desconstuição da alienação. Ficou evidente, portanto, que o síndico da massa falida não atentou à regra de que somente a alienação do estabelecimento, ou do conjunto de bens essenciais ao exercício da empresa, pode ser declarada objetivamente ineficaz. Tratando-se de bens sociais que não estejam afetados à empresa, a hipótese reclama ajuizamento de ação revocatória escorada pelo art. 130 da LRF e depende da produção da prova de fraude e dano à massa, elementos 
essenciais ao julgamento favorável.

Caso 2: a decisão proferida pela Terceira Turma do STJ no Recurso Especial n. 1.567.492/RJ, julgado em 25/10/2016, sob a relatoria do Min. Moura Ribeiro atesta a necessidade de demonstração do consilium fraudis por parte de todos os contratantes que adquiriram o bem que se pretendia devolver à massa, não bastando que, na sucessão de alienações, se demonstrasse a má-fé somente do primeiro adquirente:

FRAUDE NA ALIENAÇÃO. NECESSIDADE DE COMPROVAÇÃO DA MÁ-FÉ PARA A NULIDADE DA ALIENAÇÃO. ARTS. 53 e 55, PARÁGRAFO ÚNICO, III, A, DO DECRETO-LEI N ${ }^{\circ}$ 7.661/45. [...] 4. O art. 53 do Decreto-lei n ${ }^{\circ}$ 7.661/45 prevê a possibilidade de revogação do ato praticado pelo falido com a intenção de prejudicar os credores, desde que seja provada a fraude. 5 . O art. 55, parágrafo único, III, a, do Decreto-lei $\mathrm{n}^{\circ} 7.661 / 45$, por sua vez, dispõe que a ação revocatória pode ser proposta contra o terceiro adquirente se este tiver conhecimento, ao se criar o direito, da intenção do falido de prejudicar os credores. 6. Assim, ainda que revogada a primeira venda em razão da existência de fraude, este efeito apenas alcança as partes que agiram em conluio contra os credores da massa falida. Dessa forma, para que a segunda venda seja desconstituída é necessária a prova da má-fé, pois devem ser resguardados os interesses dos terceiros de boa-fé. 7. Ocorre que o Tribunal de origem apenas reconheceu a existência do consilium fraudis em relação à primeira adquirente, mas não quanto à alienação subsequente, entendendo que tal comprovação não era necessária. 8. Contudo, a segunda venda não poderia ter sido anulada sob a justificativa de ser essa a consequência direta da invalidade do negócio antecedente, uma vez que essa solução contraria o disposto nos arts. 53 e 55, parágrafo único, III, a, do Decreto-lei $n^{\circ}$ 7.661/45. [grifos nossos].

Conforme se extrai do relatório do acórdão do Recurso Especial, a Décima Câmara Cível do Tribunal de Justiça do Estado do Rio de Janeiro (TJRJ) manteve a sentença de procedência da ação revocatória ajuizada pela massa para decretar "a ineficácia da alienação do estabelecimento empresarial" pertencente à falida em favor da Adquirente A, e desta em favor da Adquirente B. De acordo com a decisão, o imóvel alienado deveria retornar ao ativo da massa, para posterior arrecadação pelo síndico.

No que se refere à primeira alienação, entre a falida e a Adquirente A, o Tribunal entendeu ter havido consilium fraudis, uma vez que no momento dessa alienação a falida já tinha vários títulos protestados. Pelo que consta dos autos, a Adquirente A não poderia alegar desconhecimento sobre o estado pré-falimentar da sociedade com a qual negociava, haja vista que a venda do referido imóvel representou considerável diminuição no patrimônio da sociedade e ocorreu sem a ciência dos credores, restando demonstrada a fraude. Já em relação à Adquirente B, o Tribunal entendeu pela desnecessidade de demonstrar sua má-fé para configuração da fraude, em razão de já ter havido declaração de ineficácia em relação à 
primeira alienação. Ficou ressalvado, no entanto, o direito de a Adquirente B demandar a falida, nos termos do artigo $54, \S 3^{\circ}$, do Decreto-Lei n. 7.661/45, que reconhecia tal direito.

Não obstante, a decisão do TJRJ foi reformada pela Terceira Turma do STJ, justamente por se tratar de discussão travada em sede de ação revocatória, na qual se exige a prova do conhecimento do estado pré-falimentar da sociedade com a qual se negocia para demonstração da intenção do falido de prejudicar os credores.

Ainda que fosse considerada ineficaz a primeira venda, diante da constatação de fraude, tal efeito operaria apenas inter pars que, em tese, agiram em conluio (o falido e a Adquirente "A") em prejuízo dos credores da massa. Dessa forma, para que a alienação seguinte, firmada com a Adquirente $\mathrm{B}$, fosse desconstituída seria necessário provar sua má-fé atuando em conjunto com a falida. Este entendimento do STJ caminha no sentido de resguardar os interesses dos terceiros de boa-fé, pois não se tratou de simples declaração de ineficácia objetiva de negócio jurídico (art. 129 da LRF). Como não havia nos autos elementos que permitissem concluir pela existência ou não de má-fé por parte da Adquirente $B$, o que importaria, inclusive, em revolver matéria de prova, com óbice na Súmula n. 7 do STJ, foi determinado o retorno dos autos ao TJRJ para apreciação da suposta prática de conluio fraudulento da falida em relação à Adquirente $\mathrm{B}$.

No caso sob análise, a decisão do STJ está alinhada à interpretação a ser dada aos casos de ineficácia subjetiva, passíveis "revocação" em favor da massa. Destarte, é curial a produção da prova de fraude, que não restou demonstrada pela massa falida, não se podendo descartar a hipótese de a segunda alienação ter ocorrido de boa-fé pela Adquirente B. O caso também se presta a elucidar que a ineficácia do art. 130 não atinge o terceiro de boa-fé, que poderá reclamar perdas e danos em face do devedor - art. 136, § $2^{\circ}$, LRF) - apenas quando se tratar de hipótese de ineficácia objetiva, prevista em um dos incisos do art. 129 da LRF.

Caso 3: a terceira decisão foi proferida pela Quinta Câmara Cível do Tribunal de Justiça do Rio Grande do Sul (TJRS), no Recurso de Apelação n. 70059099101, julgado em 30/04/2014, sob a relatoria da Des. Isabel Dias Almeida. O julgado confirma a dificuldade na produção de prova do conhecimento, por parte dos terceiros adquirentes, do prejuízo causado aos credores do falido com a efetivação do negócio jurídico que se pretendia revogar:

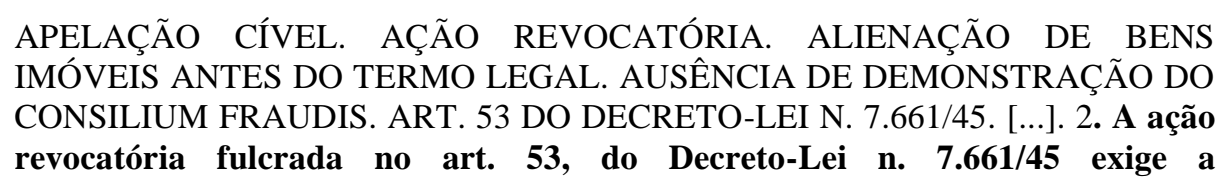


demonstração do consilium fraudis, situação não verificada na espécie. Sentença de improcedência mantida. RECURSO DESPROVIDO. [grifo nosso]

Conforme se colhe do relatório do acórdão, a massa falida autora ingressou com ação revocatória com intuito de obter a decretação de ineficácia da venda de quatro imóveis que pertenciam ao ex-sócio da falida, cuja personalidade jurídica foi desconsiderada, justamente para que lhe fossem restituídos os bens alienados em prejuízo da massa e dos credores. Nos autos do processo, ficou demonstrado que o ex-sócio alienou seus bens por cerca de $60 \%$ do valor efetivamente devido, ou seja, por quantia abaixo do valor de mercado. Embora os imóveis tenham sido subavaliados, o TJRS não considerou vil o valor praticado na venda, entendendo que inexistiram no caso concreto elementos capazes de demonstrar que os terceiros adquirentes tinham ciência (scientia fraudis) da condição pré-falimentar da devedora. Neste caso, é relevante lembrar que a ciência quanto à condição de endividamento do vendedor é elemento útil à comprovação do consilium fraudis.

Na fundamentação do acórdão, os julgadores ponderaram que a realização do negócio ocorreu cerca de cinco meses antes da fixação do termo legal, e que não foram carreadas aos autos provas de que os terceiros adquirentes tinham ciência de atos de dilapidação patrimonial. O único elemento prepoderante para a pretensão da massa falida foi o fato de os imóveis terem sido vendidos por valor abaixo do preço de mercado, porém, tal constatação, por si só, não foi considerada suficiente para procedência do pedido.

Urge destacar, como elemento fundamental de improcedência da ação revocatória em comento, a ausência de prova quanto a ciência dos terceiros adquirentes acerca do estado préfalimentar da sociedade do qual o alienante era sócio. Nesse cenário, é possível cogitar da assimetria de informações ${ }^{23}$ entre a massa falida e o réu da ação revocatória, isto é, o ex-sócio que alienou os bens que poderiam ser utilizados para o pagamento aos credores.

Caso 4: a decisão foi proferida pela Quinta Câmara Cível do Tribunal de Justiça do Estado de Minas Gerais (TJMG), no Recurso de Apelação n. 10024142601889001, julgado em 12/04/2018, sob a relatoria da Des. Áurea Brasil. O julgado se presta a demonstrar, uma vez mais, a imperícia do administrador judicial ao propor ação, elegendo o dispositivo equivocado para amparar sua pretensão e, consequentemente, deixando de produzir a prova necessária à

23 É possível cogitar que, na ação revocatória, o réu detenha mais informações, documentos e provas do que o próprio autor da medida, materializando-se a assimetria de informações entre as partes demandante e demandada. Como consequência disso, dificulta-se a adequada instrução do processo. 
revogação do ato que se pretendia desconstituir em relação à massa.

\begin{abstract}
APELAÇÕES CÍVEIS - AÇÃO REVOCATÓRIA. PRELIMINAR - [...] MÉRITO SUCESSIVOS CONTRATOS DE COMPRA E VENDA DE VEÍCULO DA FALIDA - ALIENAÇÃO DE ESTABELECIMENTO COMERCIAL - AUSÊNCIA DE DEMONSTRAÇÃO - INAPLICABILIDADE DO ART. 129, INCISO VI DA LEI N. 11.101/2005 - ATO DO FALIDO OBJETIVAMENTE INEFICAZ - AFASTADO CONLUIO FRAUDULENTO ENTRE O DEVEDOR E O TERCEIRO QUE COM ELE CONTRATOU - NÃO DEMONSTRAÇÃO - IMPROCEDÊNCIA DO PEDIDO [...] 2. Para configuração da hipótese descrita no inciso VI do art. 129 da Lei n. 11.101/2005, imprescindível que haja a venda ou transferência de estabelecimento comercial, o qual é definido, nos termos do art. 1.142 do Código Civil, como sendo complexo de bens organizado, para exercício da empresa, por empresário, ou por sociedade empresária. 3 . A venda isolada de veículo não configura contrato de trespasse, a atrair a incidência do regramento do inciso VI do art. 129 da Lei n. 11.101/2005, a não ser que seja demonstrada a sua essencialidade para a empresa e o desmantelamento do fundo de comércio da falida com a alienação - o que não ocorreu no caso. 4. Inaplicabilidade do art. 130 da Lei n. 11.101/2005, tendo em vista que não restou comprovada a intenção de prejudicar credores, provando-se o conluio fraudulento entre o devedor e os terceiros adquirentes. [grifos nossos]
\end{abstract}

A massa falida ajuizou ação revocatória com vistas à declaração de ineficácia dos contratos de compra e venda de veículo automotor (caminhão), celebrada pela sociedade falida com a Adquirente A, em seguida, por esta com o Adquirente B e, por fim, desse último com o Adquirente C. A pretensão foi equivocadamente amparada no artigo 129, VI, da LRF, defendendo a autora que os atos impugnados se enquadrariam na referida hipótese legal, não sendo necessária a demonstração da intenção dos contratantes de fraudar credores. No entanto, confome registrado pela relatora, alguns Tribunais não têm observado a diferença crucial existente entre alienação do estabelecimento e dos bens que o compõem.

A LRF ataca com ineficácia objetiva o trespasse quando realizado sem a observância de certos pressupostos (anuência ou ciência expressa dos credores que podem apresentar oposição), mas não a alienação de elementos integrantes do estabelecimento empresarial, quando realizada de modo isolado e sem caracterizar seu desmantelamento. Assim, o Tribunal entendeu que a venda do veículo automotor, isoladamente, não configurou trespasse, a invocar a expressa aplicação do inciso VI do art. 129 da LRF. Com a inaplicabilidade do referido dispositivo, os sucessivos contratos de compra e venda poderiam ser revogados na forma do art. 130 da LRF, porém, para que tal desconstituição fosse possível, seria necessário comprovar o consilium fraudis entre a falida, a devedora e os terceiros adquirentes do veículo.

Nota-se, da análise do julgado, que se parte de uma premissa equivocada e, levada pela imperícia do administrador judicial que a representava, a massa falida sequer sustentou a 


\section{A IMPORTÂNCIA DA CORRETA AFERIÇÃO DOS ELEMENTOS CONSTITUTIVOS DA AÇÃO REVOCATÓRIA PARA OS CREDORES E PARA A MASSA FALIDA}

má-fé dos compradores, tendo a todo tempo defendido a prescindibilidade dessa prova por acreditar se tratar de hipótese de ineficácia objetiva do negócio que pretendia revogar. Sem a produção de prova do conluio fraudulento restou impossível a aplicação e incidência do art. 130 da LRF, tendo sido reformada a sentença de $1^{\circ}$ grau para julgar improcedente o pedido.

Caso 5: a quinta decisão, proferida pela Quarta Turma do STJ no Recurso Especial n. 806.044/RS, julgado em 06/04/2010, sob a relatoria do Min. Luis Felipe Salomão, reforça a correta identificação do dispositivo adequado à revogação pretendida pela massa falida e demonstra que sua inobservância acarreta o insucesso da ação revocatória.

FALÊNCIA. AÇÃO REVOCATÓRIA. ALIENAÇÃO DE BEM REALIZADA NO
TERMO LEGAL DA FALÊNCIA. INEFICÁCIA QUE DEPENDE DE PROVA DA
OCORRÊNCIA DE FRAUDE A CREDORES. 1. A alienação de bem pertencente à
falida, realizada dentro do termo legal, mas antes da decretação da quebra, não se
subsume ao art. 52, inciso VII, da antiga Lei de Falências, mas, eventualmente, ao
art. 53, dependendo a ineficácia do negócio, em relação à massa, de prova da
ocorrência de fraude a credores. 2. A interpretação sistemática do caput do art. $52 \mathrm{e}$
do seu inciso VII, da antiga Lei de Falências, conduz à conclusão de que somente as
transcrições de transferência de propriedade realizadas após a quebra serão tidas por
objetivamente ineficazes em relação à massa, "tenha ou não o contratante
conhecimento do estado econômico do devedor, seja ou não intenção deste fraudar
credores" [...].

O caso sob análise versa sobre ação revocatória ajuizada pela massa, por meio da qual se pretendeu ver declarada ineficácia objetiva da alienação de veículo automotor de propriedade da falida. A primeira e a segunda alienação ocorreram dentro do termo legal.

O pedido foi julgado procedente pelo Juízo da Segunda Vara Cível da Comarca de Venâncio Aires, sendo declarada a ineficácia objetiva da alienação do veículo. Em sede de apelação, o réu da ação revocatória, até então vencido, alegou cerceamento de defesa, pois foi indeferida a produção de prova pericial por ele requerida. Em síntese, o réu pretendia demonstrar com a perícia a destinação dos valores pagos pela aquisição do veículo, bem como se a operação foi devidamente contabilizada (ou não) pela sociedade. A sentença foi mantida pela Quinta Câmara Cível do TJRS, confirmando a desnecessidade de produção prova da fraude, porque os julgadores entenderem inútil a verificação do caráter subjetivo do negócio.

No julgamento do Recurso Especial interposto pelo terceiro adquirente, a Quarta Turma do STJ reformou a sentença e o acórdão das instâncias ordinárias, para julgar improcedente o pedido inicial da ação revocatória. Este julgado se tornou paradigmático em diversos outros casos e revela o desconhecimento e a equivocada utilização dos dispositivos legais que tratam da ineficácia relativa por parte da massa falida. A improcedência pode ser 
creditada à própria massa falida, no momento em que esta pugnou pelo julgamento antecipado da lide, deixando de comprovar o necessário consilium fraudis e de observar que a hipótese tratada nos autos não se amoldava à ineficácia objetiva, prevista à época pelo art. 52 do Decreto-lei n. 7.661/45, e sim de ato revogável, nos moldes do atual art. 130 da LRF.

Caso 6: a última decisão, proferida pela Quinta Câmara Cível do TJRS, no Recurso de Apelação n. 70028062156, julgado em 12/08/2009, sob a relatoria do Des. Romeu Marques Ribeiro Filho, se presta a demonstrar a dificuldade na coleta da prova cabal da má-fé do terceiro adquirirente, a fim de suprir a necessária demonstração de conhecimento quanto ao prejuízo causado aos credores.

APELAÇÃO CÍVEL. FALÊNCIA E CONCORDATA. [...] ALEGAÇÃO DA MASSA DE INEFICÁCIA DA CONTRATAÇÃO. AÇÃO REVOCATÓRIA. ART. 53 DA LEI DE FALÊNCIAS. CONSILIUM FRAUDIS NÃO DEMONSTRADO. A ação revocatória exige a demonstração do consilium fraudis entre o falido e o terceiro com quem contratou. Não há indícios nos autos de que tenham os embargantes, ao adquirir o imóvel da embargada, agido com má-fé, ou seja, com a intenção de fraudar. Sentença mantida. Apelo desprovido. [grifo nosso]

Trata-se de embargos de terceiro ajuizados nos autos da ação de falência, na qual se promoveu arrecadação de imóvel adquirido pelos embargantes. O contrato de alienação do imóvel foi firmado entre os embargantes e a devedora em 1992, enquanto que o pedido de falência ocorreu em 1999, cerca de sete anos após o negócio jurídico que se pretendia revogar.

A sentença de $1^{\circ}$ grau, mantida pelo TJRS, concluiu que não foram apresentados indícios suficientes para comprovar que os embargantes tenham agido de má-fé ao adquirir o imóvel da devedora. A autora alegou que os embargantes tinham ciência da irregularidade do negócio, pois na ocasião da venda do imóvel a sociedade não fornecera a Certidão Negativa de Débitos (CND), fato que teria inviabilizado o registro da venda do imóvel.

O juízo da Vara de Falências e Concordatas da Comarca de Novo Hamburgo e a Quinta Câmara Cível do TJRS entenderam que a existência de débitos em nome da falida não enseja fraude, não sendo crível que os embargantes pretendessem a aquisição de um imóvel cientes da impossibilidade de seu registro. Embora a massa falida tenha corretamente alegado a incidência do art. 53 do Decreto-lei n. 7.661/45 (ineficácia subjetiva do negócio jurídico em relação a ela), o Tribunal entendeu que a má-fé dos adquirentes do imóvel não ficou evidenciada, ou seja, os julgadores inferiram que estaria ausente o consilium fraudis.

Percebe-se que a mera impossibilidade de obtenção da CND do imóvel não foi suficiente para configuração da fraude e do consequente reconhecimento da ineficácia 


\section{A IMPORTÂNCIA DA CORRETA AFERIÇÃO DOS ELEMENTOS CONSTITUTIVOS DA AÇÃO REVOCATÓRIA PARA OS CREDORES E PARA A MASSA FALIDA}

pretendida. A anterioridade do negócio em relação à falência mostrou-se fator decisivo na manutenção de sua eficácia. Nessa hipótese, também pode-se cogitar de assimetria das informações detidas pela massa falida e pelo réu da revocatória. A impossibilidade de obtenção de CND poderia representar indícios de dificuldades financeiras já enfrentadas pela devedora ao tempo da alienação, contudo restaram ausentes elementos mais contundentes quanto à configuração real da fraude, indispensável à desconstituição do negócio pretendido.

\section{CONCLUSÃO}

Verificou-se que, usualmente, há imperícia do administrador judicial no ajuizamento da ação revocatória, evidenciada pela quantidade de processos abertos com fundamento em dispositivos equivocados e nos quais, não raramente, se dispensou a oportunidade de produção de provas essenciais para adequada demonstração do fato constitutivo do direito do autor da revocatória, unicamente por se acreditar que se tratava de ineficácia objetiva.

Além da imperícia, outro elemento que se mostra como possível causa das improcedências aqui narradas é a assimetria de informações detidas pela massa falida, como autora da ação revocatória, e o réu da ação, que pode ser o sócio da falida ou terceiro adquirente que se beneficiou com aquisição de bem a preço vil, ou, no mínimo, subavaliado pela sociedade que se encontrava em estado pré-falimentar.

Também há que se cogitar da dificuldade na coleta de provas que, em certas ocasiões inexistem e, em outras, são destruídas justamente por aqueles que - futuramente - ocuparão o polo passivo da revocatória. Evidentemente que se houver intenção ou ciência do prejuízo causado à massa falida, em razão do negócio entabulado, o réu será o último a apresentar nos autos a prova capaz de desnudar o enredo travado em uma operação fraudulenta.

Por fim, especialmente no momento hodierno, em que se constata o processamento de centenas de pedidos de recuperação judicial, é importante o estudo sobre os efeitos de eventual insucesso desses processos de reestruração em caso de convolação em falência. Como consequência do interesse público envolvido no processo falimentar e no desejo de que a realização do ativo seja suficiente para satisfazer os débitos do falido, o estudo da ação revocatória se mostra relevante e merece a devida atenção dos pesquisadores.

\section{REFERÊNCIAS}

Revista Brasileira de Direito Empresarial | e-ISSN: 2526-0235| Porto Alegre | v. 4 | n. 2 |

p. $79-101$ | Jul/Dez. 2018 
BRASIL. Superior Tribunal de Justiça. Agravo Interno no Recurso Especial n. 901.010/SC. Quarta Turma. Rel.: Min. Luis Felipe Salomão. Brasília, 23 de agosto de 2016. Disponível em <http://www.stj.jus.br>. Acesso em 12 ago. 2018.

Agravo Interno no Recurso Especial n. 1.294.462/GO. Quarta Turma. Rel.: Min. Lázaro Ramos seguindo voto-vista do Min. Luis Felipe Salomão. Brasília, 19 de outubro de 2017. Disponível em <http://www.stj.jus.br>. Acesso em 12 ago. 2018.

Recurso Especial n. 1.180.714/RJ. Quarta Turma. Rel.: Min. Luis Felipe Salomão. Brasília, 04 de abril de 2011. Disponível em <http://www.stj.jus.br>. Acesso em 12 ago. 2018.

Recurso Especial n. 1.197.723/SP. Quarta Turma. Rel.: Min. João Otávio de Noronha. Brasília, 19 de outubro de 2010. Disponível em <http://www.stj.jus.br >. Acesso em 12 ago. 2018.

Recurso Especial n. 1.567.492/RJ. Terceira Turma. Rel.: Min. Moura Ribeiro. Brasília, 25 de outubro de 2016. Disponível em <http://www.stj.jus.br>. Acesso em 12 ago. 2018.

Recurso Especial n. 806.044/RS. Quarta Turma. Rel.: Min. Luis Felipe Salomão. Brasília, 06 de abril de 2010. Disponível em <http://www.stj.jus.br >. Acesso em 12 ago. 2018.

CAHALI, Yussef Said. Fraude contra credores: fraude contra credores, fraude à execução, ação revocatoria falencial, fraude à execução fiscal e fraude à execução penal. 5. ed.. rev. atual. São Paulo: Editora Revista dos Tribunais, 2013.

CAMPINHO, Sérgio. Curso de direito comercial: falência e recuperação de empresa. 9. ed.. São Paulo: Saraiva Educação, 2018.

CLARO, Carlos Roberto. Revocatória Falimentar: de acordo com a nova lei de falências. 3. ed.. rev. atual. e ampl. com base na Lei 11.101 de 09.02.2005. Curitiba: Juruá Editora, 2005.

GONÇALVES, Carlos Roberto. Direito civil brasileiro. v. I: parte geral. 5. ed.. rev. atual. São Paulo: Saraiva, 2007.

LEONEL, Jayme. Da Ação Revocatória no Direito da Falência. 2. ed.. São Paulo: Saraiva, 1951.

MARTIN, Antonio. Seção IX: Da Ineficácia e da revogação de atos praticados antes da falência. In.: SOUZA JUNIOR, Francisco Satiro; PITOMBO, Antônio Sérgio A. de Moraes (Coord.). Comentários à Lei de recuperação de empresas e falência: Lei 11.101/2005. São Paulo: Editora Revista dos Tribunais, 2007.

MENDONÇA, José Xavier Carvalho de. Tratado de direito comercial brasileiro. v. VII. 7. ed.. Rio de Janeiro: Freitas Bastos, 1964.

MINAS GERAIS (Estado). Tribunal de Justiça. Recurso de Apelação n. 10024142601889001. Quinta Câmara Cível. Rel. Desembargadora Áurea Brasil. Belo Horizonte, 12 de abril de 2018. Disponível em <http://www4.tjmg.jus.br>. Acesso em 12 ago. 2018.

REQUIÃO, Rubens. Curso de direito falimentar. v. I. 17.ed. São Paulo: Saraiva, 1998.

REVISTA VALOR ECONÔMICO. Editorial. Pedidos de recuperação judicial batem recorde

Revista Brasileira de Direito Empresarial | e-ISSN: 2526-0235| Porto Alegre | v. 4 | n. 2 |

p. $79-101$ | Jul/Dez. 2018 
em 2016, nota Serasa Disponível em <https://www.valor.com.br/brasil/4824392/pedidos-derecuperacao-judicial-batem-recorde-em-2016-nota-serasa> Acesso em 08 ago. 2018.

RIO GRANDE DO SUL (Estado). Tribunal de Justiça. Recurso de Apelação n. 70059099101. Quinta Câmara Cível. Rel.: Desembargadora Isabel Dias Almeida. Porto Alegre, 30 de abril de 2014. Disponível em <http://www.tjrs.jus.br>. Acesso em 12 ago. 2018.

Recurso de Apelação n. 70028062156. Apelante: Massa Falida de S. N. Muller e Cia. Ltda. Quinta Câmara Cível. Rel.: Desembargador Romeu Marques Ribeiro Filho. Porto Alegre, 12 de agosto de 2009. Disponível em <http://www.tjrs.jus.br>. Acesso em 12 ago. 2018.

SANTA CATARINA (Estado). Tribunal de Justiça. Recurso de Apelação n. 20120861326. Câmara de Direito Público. Rel.: Desembargador Cid Goulart. Florianópolis, 22 de julho de 2013. Disponível em <esaj.tjsc.jus.br>. Acesso em 12 ago. 2018.

TEPEDINO, Ricardo. Seção VI. Da falência requerida pelo próprio devedor. In.: ABRÃO, Carlos Henrique; TOLEDO, Paulo F. C. Salles (Coord.). Comentários à Lei de recuperação de empresas e falência. 6. ed.. rev., atual. e ampl. - São Paulo: Saraiva, 2016.

VALLE, Christino Almeida do. Teoria e prática da ação revocatória. Rio de Janeiro: AIDE Editora, 1987.

VALVERDE, Trajano de Miranda. Comentários à Lei de Falências. v. I. 4. ed.. Rio de Janeiro: Editora Revista Forense, 1999. 